\title{
Gizli Sınıf Analizi ile Türkiye'de Cinsiyet Eşitsizliğine bakış Açısının Değerlendirilmesi
}

\author{
Evaluation of Perspective on Cender Inequality in Turkey Using Latent Class Analysis
}

\author{
Enescan Deveci ${ }^{1}$ iD, Özlem Yorulmaz ${ }^{2}$ iD
}

\section{Ö Z}

Toplumsal hayatta kadın ve erkeklerin eğitim, çalışma hayatı ve çeşitli sosyal alanlarda eşit olarak görülmemesi bir sorun olarak karşımıza çıkmaktadır. Bireylerin cinsiyetleri nedeniyle maruz kaldıkları eşit olmayan tutum ve davranışların şekillenmesinde gelenek ve görenekler önemli rol oynar. Kadın ve erkeklerin toplumsal yaşamın her alanında eşit söz sahibi olmaları bir gelişmişlik göstergesi olan İnsani Gelişmişlik İndeksi'nin de bileşenlerinden birini oluşturur. Birçok ülke çeşitli politikalarla toplumsal cinsiyet eşitliğini desteklemektedir. Literatürde yer alan çeşitli çalışmalarda ekonomik büyüme ve cinsiyet eşitliğinin birbirini desteklediği görülmüştür. Cinsiyet eşitliği sadece toplumsal gelişim üzerinde etkili olmakla kalmayıp aynı zamanda kadınların yaşam kalitesi üzerinde de bir etkiye sahiptir. Bu çalışmada, bireylerin sosyo-ekonomik ve demografik özelliklerinin, politik görüşlerinin, demokrasiye olan inançlarının ve dindarlık düzeylerinin cinsiyet eşitsizliği kavramına bakış açıları üzerindeki etkileri değerlendirilmiştir. Dünya Değerler Anket verisinden hareketle Gizli Sınıf Analizi ile yapılan değerlendirmede toplumun cinsiyet eşitsizliği hakkındaki düşüncelerinin genel olarak iki farklı sınıfta incelenebileceğini sonucuna ulaşılmıştır. $\mathrm{Bu}$ sınıfların belirleyiciliği üzerinde etkili olan değişkenler eğitim düzeyi, cinsiyet, politik görüş ve demokrasiye olan inanç düzeyidir. Bununla birlikte yaşın, sosyal statünün ve dindarlık düzeyinin bu grupların belirlenmesinde önemli olmadığı görülmüştür.

Anahtar Kelimeler: Cinsiyet Eşitsizliği, Gizli sınıf analizi, Toplumsal cinsiyet.

Jel Sinıflaması: C4, I31, J7.

\section{A B S T R A C T}

It is a problem that women and men are not seen as equal in education, working life and various social areas in social life. Traditions and customs play an important role in shaping the unequal attitudes and behaviors that individuals are exposed to due to their gender. The fact that women and men have an equal right in all areas of social life is one of the components of the Human Development Index, which is an indicator of development. Many countries support gender equality through various policies. In various studies in the literature, it has been seen that economic growth and gender equality support each other. Gender equality not only has an impact on social development, but also has an impact on women's quality of life and even health. In this study, the effects of socio-economic and demographic factors, political views, religioisty and belief in democracy, which are known to be effective on individuals' perspectives on gender inequality, were examined. Based on the World Values Survey data, the evaluation made with the Latent Class Analysis showed that the opinions of the society about gender inequality can be examined in two different classes. The variables that affect the determination of these groups are the level of education, gender, political view and belief in democracy. However, it is seen that age, social status and level of religiosity are not important in determining these groups.

Keywords: Gender inequality, latent class analysis, social gender.

\section{DOI: 10.47934/tife.10.02.05}

*Bu çalışma, İstanbul Üniversitesi Sosyal Bilimler Enstitüsü İstatistik Yüksek Lisans Programı'nda Enescan Develi tarafından kaleme alınan "Gizli Sınıf Analizi ile Türkiye'de Cinsiyet Eşitsizliğine Bakış Açısının Değerlendirilmesi" başlıklı tezden türetilmiştir.

1. Kıdemli Uzman, Ziraat Bankası. ORCID: 0000-0002-2214-8597

2. Doç.Dr, İstanbul Üniversitesi. ORCID: 0000-0003-1029-5749

SORUMlu Yazar / CoRResponding AUTHOR

Enescan Deveci,

Kıdemli Uzman, Ziraat Bankası.

E-mail: enescan_deveci@hotmail.com

$\begin{array}{ll}\text { BAŞVURU/SUBMITTED: } & 08.10 .2021 \\ \text { REVIZYON TALEBI/ } & \\ \text { REVISION REQUESTED: } & 16.11 .2021 \\ \text { SON REVIZYON/ } & \\ \text { LAST REVISION : } & 22.11 .2021 \\ \text { KABUL/ACCEPTED: } & 22.11 .2021\end{array}$

Atıf / Citation: Deveci, E., Yorulmaz, Ö. (2021). Gizli Sınıf Analizi ile Türkiye'de Cinsiyet Eşitsizliğine bakış Açısının Değerlendirilmesi. Trakya Üniversitesi İktisadi ve İdari Bilimler Fakültesi e-Dergi, 10(2), 130144, https://doi.org/10.47934/tife.10.02.05 


\section{Giriş}

Bireyler çoğunlukla yaş, cinsiyet, sosyal statü, ekonomik durum ve ırk gibi değişkenler dikkate alınarak sınıflandırılır. Bu değişkenler içerisinde yer alan "cinsiyet" akla ilk olarak "kadın" ve "erkek" olma halini getiriyor olsa da aslında cinsiyet bu biyolojik anlamının ötesinde anlamlar içerir. Cinsiyet bireylerin toplumdaki davranış biçimlerini, rollerini hatta yaşam standartlarını belirler (Akkaş, 2019). Cinsiyet kavramı evrensel olup tıp, biyoloji, sosyoloji, psikoloji, din, felsefe vb. gibi bilim dallarının araştırma konusu olarak karşımıza çıkmıştır (Uzgan, 2018).

Bireylerin dünyaya gelme aşamasında biyolojik merkezli bir anlam taşıyan cinsiyet, zamanla toplum normlarına uyulmaya başlanması ile toplum merkezli anlam içermeye başlar. Aslında toplum, kadın ve erkeğin nasıl davranacağı konusundaki beklentilerin yapılandırıldığı alandır (Çiçekli, 2019). Toplumsal cinsiyet kavramı ise, gelenek, görenek ve adetler gibi toplumsal faktörlere göre şekillenir. Toplumsal cinsiyet, bireylerin toplum içerisindeki konumunu, kadın ve erkeğin iş bölümünü ve sosyoekonomik statüyü şekillendirmekte öne çıkar. Bu kavram bireylerin toplum içerisindeki rollerini atar ve günlük yaşamı düzenler. Toplumsal cinsiyet, biyolojik gen ve cinsiyet gibi somut kavramlara manevi anlamlar yükleyerek bu kavramları kültürel olarak tanımlar ve ayrıştırır. Toplumsal cinsiyette karşımıza çıkan en önemli sorun, kadın ve erkeklere sunulan eşit olmayan koşullar noktasında açığa çıkar.

Doğuşta eşit olarak dünyaya gelen iki cins, toplum tarafından belirlenen roller ve sorumluluklar neticesinde eşit olmaktan uzaklaşır, bu durum cinsiyet eşitsizliği kavramını açığa çıkarır. Toplumsal cinsiyet eşitsizliği kavramı toplumsal cinsiyetin karşımıza çıkardığı önemli bir sorundur. Bu kavramla beraber cinsiyet eşitliği ve cinsiyet eşitsizliği kavramları da doğmuştur. Toplumsal cinsiyet eşitliği kavramı, insanların yaşadıkları toplumda sahip oldukları haklar açısından bir ayrımcılığa maruz kalmamasıdır. Bu durum ancak sınıflar arasındaki farklılıkların ortadan kalkması ve toplumsal cinsiyet eşitliği kavramının benimsenmesiyle sağlanır. Eşitsizlik olarak anlatılmak istenen, bireylere toplumsal cinsiyetleri açısından eşit davranılmaması durumudur. Toplumsal cinsiyet eşitliği, kadının ve erkeğin toplumdaki görevlerinin önemini eşit olarak kabul etmekle beraber, aynı zamanda kadın ve erkeğin biyolojik olarak farklarının göz önünde bulundurulmasıdır (Uzgan, 2018).

Kadın ve erkeklerin toplumda sahip olduğu statü ve saygınlığın dengesiz olarak dağılması, eşitsiz güç ilişkileri olarak isimlendirilir. Erkeklere oranla kadınların iş dünyasında daha geride olmaları, çoğunlukla kadınların ev hanımı olarak görülmesi, siyasal anlamda kadınları temsil eden kadın sayısının az olması ve yönetici pozisyonunda olan kadın sayısının erkeklere göre az olması gibi durumlar, eşit olmayan güç ilişkilerinin kadın-erkek arasındaki en somut örnekleridir (Savaş, 2018). Cinsiyet Eşitsizliği, erkek ve kız çocukları ile yetişkin erkek ve kadınlar arasındaki güç, statü, haklar ve fırsatlar bakımından eşitsizlik ve dengesizlik durumudur (Uluocak, 2014).

Cinsiyet eşitsizliğinin önüne geçilmesi kadın ve erkeklerin tüm kamusal alan ve ortak alanlarda eşit statüye sahip olması, bu alanlara eşit düzeyde katılması ve eşit görülmesi ile mümkündür. Aileden topluma kadar her alanda kadın ve erkeğin kaynaklardan, fırsatlardan ve sunulan hizmetlerden eşit şekilde yararlanması, yasalar önünde kadın ve erkeğe eşit davranılması gerekmektedir. Buradaki eşitlik kavramı kadın ve erkeğin biyolojik farklılığına bakılmaksızın birey olarak değerlendirilmesi olarak ifade edilir (Akkaş, 2019).

Literatürde, bireylerin toplumsal cinsiyet eşitsizliğine bakış açılarını etkileyen faktörler incelendiğinde cinsiyet, eğitim, yaş, medeni hal, ekonomik durum ve dindarlık düzeyinin öne çıtı̆̆ı gözlemlenmiştir. Bu çalışma, Türkiye'de bireylerin cinsiyet eşitsizliğine bakış açısını farklı yargılardan hareketle sınıflayan ve bu sınıfları birbirinden ayıran dinamikleri inceleyen bir çalışma olarak literatüre katkı yapmayı hedeflemektedir. Çalışmada öncelikli olarak cinsiyet, toplumsal cinsiyet, cinsiyet eşitsizliği kavramlarına ve bu konuda öne çıkan çalışmalara yer verilmiştir. Sonrasında çalışmada yöntem olarak 
benimsenen Gizli Sınıf Analizi detaylı bir şekilde açıklanmış, analizde kullanılan Dünya Değerler Anket verisi ve değişkenler tanımlanmış, son olarak da Gizli Sınıf Analizi bulguları doğrultusunda yazılan sonuç ile çalışma tamamlanmıştır.

\section{Literatür}

Dünyada ve Avrupa'da 70'li yıllara dayanan kadın erkek eşitliği konusunun kurumsallaşma süreciyle beraber Türkiye'de de kadın erkek eşitliği konusunda adımlar atılması ve devlet sorumluluğunda ilerlemesi fikri benimsenmiştir. Kadınlara Karşı Her Türlü Ayrımcılığın Önlenmesi Sözleşmesi'ni (CEDAW) 1985 yılında imzalayan Türkiye bunun üzerine 20 Nisan 1990 tarihinde Kadın Statüsü ve Sorunları Başkanlığını kurarak eşitlik içinde kadının ilerleyerek hak ettiği statüyü kazanmasını amaçlamıştır. Son yıllara baktığımızda, 2004 yılındaki değişiklikle Anayasanın 10'uncu maddesine "Kadınlar ve erkekler eşit haklara sahiptir. Devlet, bu eşitliğin yaşama geçmesini sağlamakla yükümlüdür" ek fıkrası eklenerek, toplumsal cinsiyet eşitliğine anayasal güvence getirildi (Başbakanlık Kadın Statüsü Raporu, 2008). 2009 yılında Kadın Erkek Fırsat Eşitliği Komisyonu, Türkiye Büyük Millet Meclisi (TMMM) tarafından kabul edilerek kuruldu ve 2012 yılında ayrıca 6284 sayılı Ailenin Korunması ve Kadına Karşı Şiddetin Önlenmesine ilişkin kanun kabul edildi.

Türkiye' de toplumsal cinsiyet eşitliğinin temelini Cumhuriyet devrimleri oluşturur. Bu devrimde yapılan reformlar sayesinde kadının yurttaşlık hakkını kazanması sağlanmıştır. Türkiye'de kadınların medeni haklarını 1926 yılında çıkan medeni kanun ile kazanmalarının yanı sıra birçok Avrupa Birliği ülkesinden daha önce 1930 yılında belediye seçimleri ve 1934 yılında genel seçimlere katılarak siyasal haklarını kazanması sağlanmıştır (Kartal, 2005).

Dünya Ekonomik Forumu tarafından ilk kez 2006 yılında toplumsal cinsiyet eşitsizliğinin boyutunu ölçmek ve zaman içindeki değişimini izlemek için tanıtılan Küresel Cinsiyet Eşitliği İndeksi, ulusal cinsiyet farklılıklarını ekonomik, eğitim, siyasi ve sağlık açısından çeşitli kriterleri dikkate alarak karşılaştırmaktadır. $\mathrm{Bu}$ indeks, toplumsal sınıflandırma ve bölgeler arasında efektif karşılaştırmalar yaparak ülke sıralamaları sunmaktadır. Birleşmiş Milletler bu sıralama sayesinde, küresel farkındalık ile cinsiyet eşitsizliğinin zorluklarını yenmeyi amaçlamıştır (Global Gender Gap Report, 2020).

Türkiye, Küresel Toplumsal Cinsiyet Eşitsizliği İndeksi'nde raporun yayınlandığı 2006 yılından beri yer almaktadır. 2006 yılındaki 115 ülkenin değerlendirildiği ilk raporda Türkiye 105. sırada yer almıştır. Bu rapora göre, "Ekonomik katılım ve fırsatlar" kategorisinde olarak 0.4344 puanını alarak sıralamada 106'ıncı, "Eğitime Ulaşma" kategorisinde 0.8889 puan alarak 92'inci, "Sağlık ve Yaşam" kategorisinde 0.9691 puan alarak 85'inci ve son olarak "Siyasi Katılım" kategorisinde 0.0516 puan alarak 96. sırada yer almıştır. (Global Gender Gap Report, 2006). Türkiye, Küresel Toplumsal Cinsiyet Eşitsizliği İndeksi' nin 2010 yılındaki, 2006, 2007, 2008, 2009 yıllarıyla kıyaslamalı olarak yayınlanan raporunda, 2006, 2007, 2008, 2009 yıllarında sırasıyla 105, 121, 123, 129 olan sırasını 2010 yılında 134 ülke arasında 126. olarak güncellemiştir. Ayrıca Türkiye, "Ekonomi” kategorisinde 131'inci, "Eğitim” kategorisinde 109'uncu, "Sağlık" kategorisinde 61'inci ve "Siyaset" kategorisinde 99.sırada yer almaktadır. Türkiye 0.5876 genel puan almıştır 2006, 2007, 2008 ve 2009 yıllarına göre yüksek bir puan almış fakat artış sınırlı kalmıştır. Dünya Ekonomik Forum'un 2015 yılındaki 10. raporunda, Türkiye 145 ülke arasında 0.624 puan alarak genel puanını yükseltmiş olsa da genel ortalamada 130. olmuştur. Türkiye "Sağlık" kategorisinde 40 ülkeyle beraber 0.980 puan alarak 1'inciliği paylaşmıştır fakat "Ekonomi" kategorisinde 0.459 puan alarak bu kategoride ilerleme gösterememiştir. Küresel Toplumsal Cinsiyet İndeksi'nin 2020 yılındaki son raporunda İzlanda, Norveç, Finlandiya ilk üçteki yerlerini korurken, Türkiye tekrar 130.sırada yer almıştır. Türkiye, 153 ülkenin katıldığı 2020 yılındaki raporda "Sağlık" alanında 64üncü, "Ekonomi" alanında 134üncü, "Eğitim" kategorisinde 114üncü ve son olarak "Siyaset" kategorisinde 109.sırada yer almıştır (Global Gender Gap Report, 2020). 
Birçok araştırma sonucuna göre cinsiyet, bireyin toplumsal cinsiyet algısını etkileyen en önemli faktörlerden biridir. İncelenen araştırmalarda toplumsal cinsiyet eşitliği kavramına bakış açısında kadın ve erkekler arasında fark oluğu anlaşılmıştır. Kadınlara göre erkeklerin daha tutucu olduğu ve kadınların toplumsal cinsiyet eşitsizliği konusunda erkeklere oranla daha bilinçli oldukları görülmüştür (Altuntaş ve Altunova, 2015). Erkekler geleneksel rollerde daha mutlu olduğundan ve kadınlara göre erkekler daha önemli görüldüğünden ötürü erkekler geleneksel anlayış içinde kalarak kadınlara göre cinsiyet eşitliğini daha az desteklemektedir (Meisenberg ve Woodley,2015).

Kadınların bilimden, siyasetten ve sosyal etkinliklerden dışlanmalarının sebebi erkekler kadar eğitim haklarının bulunmaması ve bu sebeple eğitimden yararlanamamaları olarak açıklanabilir (Tan, 2018). Devletlerin toplumsal cinsiyet eşitliği politikalarını ve görüşlerini gerçekleştirmek amacıyla eğitim, toplumsal cinsiyet temelli sivil toplum oluşumlarının kuvvetlendirilmesi açısından önemli bir yer tutmaktadır. Eğitim ve okullaşmanın artması sonucunda toplumsal cinsiyet eşitliği artmaktadır. Bu durum hem eğitimli hem de vasıfı kadınların sayısının artmasının yanı sıra istihdam ve eğitim talebi de artmakta ve çeşitlendirmektedir (Sayılan, 2016).

Önceki yüzyıllarda eğitim, toplumdaki üst sınıflarının konumlarını devam ettirebilmek için kullanılan bir araçtı. Bu durumun değişmesi ve eğitimin tüm toplum için hak olarak görülmesi aslında yeni sayılabilecek bir gelişmedir. Bu anlamda 18. yüzyılda Avrupa'da Endüstri Devrimi ve Aydınlanma Döneminin etkisiyle kadınların eğitim alanında eşitlik haklarını talep etmeleri oldukça önemlidir. Aydınlanma döneminde eğitim, değişimin ve gelişimin en önemli araçlarından biri olarak görülmüştür. Aslında eğitimin önemi ve toplumsal cinsiyet eşitliği algısının oluşmasında önemli bir rol oynadığı bu dönemde fark edilmiştir. Kadınların bilimden, siyasetten ve sosyal etkinliklerden dışlanmalarının sebebi erkekler kadar eğitim haklarının bulunmaması ve bu sebeple eğitimden yararlanamamaları olarak açıklanabilir (Tan, 2018). Devletlerin toplumsal cinsiyet eşitliği politikalarını ve görüşlerini gerçekleştirmek amacıyla eğitim, toplumsal cinsiyet temelli sivil toplum oluşumlarının kuvvetlendirilmesi açısından önemli bir yer tutmaktadır. Eğitim ve okullaşmanın artması sonucunda toplumsal cinsiyet eşitliği artmaktadır. Bu durum hem eğitimli hem de vasıflı kadınların sayının artmasının yanı sıra istihdam ve eğitim talebini arttırmakta ve çeşitlendirmektedir. Eğitimin yaygınlaşmasının az da olsa kadını güçlendirici etkisi vardır. Bu durum kadının güçlenmesiyle beraberinde toplumda cinsiyet eşitliğinin de önünü açmaktadır. Ancak müfredatların cinsiyet eşitliğini temel alacak şekilde olması ve öğretmenlerin bu konuda bilinçlenmesi sayesinde eğitimin toplumsal cinsiyet eşitliğine etkisi daha da artırılabilmektedir (Sayılan, 2012).

Cinsiyet eşitliğini artırmaya yönelik tutumlar da eğitim duruma göre farklılık göstermektedir. 21 ülkede yapılan çalışmada, daha fazla eğitime sahip olan bireylerin, daha az eğitim alan bireylere göre cinsiyet eşitliğini savunma olasılıkları daha yüksek olduğu anlaşılmıştır (Poushter vd.,2019). Bu çalışmaya göre söz konusu fark özellikle Arjantin ve Meksika'da net bir şekilde gözükmektedir. Ortaöğretim üstü eğitime sahip olan Arjantinli bireylerin \%81'i ortaöğretim ve altında eğitim alan Arjantinlilerin \%58'ine oranla daha fazla cinsiyet eşitliğini savunmaktadır. Eğitim durumu oldukça önemli olup ABD, Kanada ve $A B$ ülkeleri dahil gelişmişlik düzeyi yüksek olan ülkelerde dahi cinsiyet eşitliğine bakış açısında farklılıklar oluşmasına sebep olmaktadır (Poushter vd.,2019).

Medeni hal açısından değerlendirildiğinde, evli bireylerin bekar bireylere oranla daha fazla sosyokültürel değişkenlerin etkisinde kaldığı ve toplumsal cinsiyet eşitliği üzerinde gözlemlerinin daha çok olduğunu göstermiştir, evli olanlar bekarlara oranla toplumsal cinsiyet eşitliğine daha geniş açıdan bakabilmektedir. Evli bireylerin, bir kadının erkekle, bir erkeğin sürekli bir kadınla beraber olması hem ev içi hem de ev dışı rollerde bekarlara oranla toplumsal cinsiyet eşitliğine daha geniş açıdan bakabilmesine olanak sağlamıştır. Bekar katılımcıların, evli bireylere nazaran çok farklı görüşler bildirmemesine rağmen 
evli bireyler kadar derinlemesine ve detaylı olarak toplumsal cinsiyet eşitliği konusunda bilgi sahibi olmadığı görülmüştür(Burç, 2015).

Toplumsal cinsiyet eşitsizliği algısı açısından yaş önemli bir değişken olarak karşımıza çıkmaktadır. Yaş artıkça sosyo-kültürel yargıların daha çok önem kazandığı, bununla beraber toplumsal cinsiyet eşitliği algısının da artığı tespit edilmiştir (Burç, 2015).Pew Araştırma Merkezi tarafından gerçekleştirilen ve farklı bir bakış açısıyla değerlendirilen, 2019 yılındaki "Değişen Bir Dünya" anket sonuçlarına göre, genç yetişkinlerin, 50 yaş ve üstü yetişkinlere nazaran cinsiyet eşitliğini desteklediği ve cinsiyet eşitliği konusunda daha hassas davrandığı gözlenmiştir. Ayrıca çalışmada ülkeler bazında inceleme yapıldığında, Yunanistan'da 18 ile 29 yaşlarındaki insanların \%70'i gibi büyük bir bölümü cinsiyet eşitliğini onaylarken, 50 yaş ve üstü bireylerin \%49'u cinsiyet eşitliğini desteklemektedir. Filipinlerde erkekler ve kadınlar arasındaki eşitliği savunan bireylerde bu oran genç bireylerde \%53'ken yaşlı bireylerde bu oran \%33'e kadar düşmektedir. Tüm bunların tersine Güney Kore'de bu örüntü farklılık göstermektedir, yaşlı erişkinlerin genç erişkinlere göre daha fazla eşitlikçi olduğu dikkat çekmiştir (Poushter ve Ferrerolf, 2019).

Sosyoekonomik sınıfların oluşmasının temel belirleyicisi olan gelir düzeyi toplumsal cinsiyet eşitliği algısıyla yakından ilişkili olarak karşımıza çıkmaktadır (Burç, 2015). Ailelerin ortalama aylık geliri artıkça, toplumsal cinsiyet rollerine yönelik kabulleri arasında pozitif yönlü bir farklılaşma görüldüğü izlenmiştir (Kodan, 2013). Öte yandan, gelir düzeyinin artmasının ataerkil yapıyı güçlendirmesi ve toplumsal cinsiyet eşitliğine zarar vermesi de mümkündür.Bireylerin, gelir eşiklerindeki değişimin ve belirli kalkınma aşamalarındaki değişimlerinin, toplumsal cinsiyet eşitliğine etkisi dikkatli bir şekilde inceleme yapmayı gerektirir. Bu nedenle ekonomik düzeydeki gelişme her zaman olumlu anlamda etki yaratmayabilir. Ayrıca bireydeki ekonomik gelişme, kadınlara karşı ön yargıları kırabilir ve bireye bağımsız bir gelir akışı sağlar, ek olarak kadınlara sosyal ve ekonomik görünürlük sağlar (Eastin ve Prakash, 2013).

Derinden hissedilen, en eski ve etkili güçlerin başında gelen din, her dönemde düşünürlerin ve bilim insanlarının, insan ve toplum hayatında çok değerli bir kurum olması bakımından ilgi odağı olmuştur. Inanan insanlar, inandıkları dinin tesiriyle dünya ve dünyevi durumlara vereceği tutum ve eylemleri belirlerler. Bu kapsamda denilebilir ki toplumda konumlanan toplumsal cinsiyet eşitliğinin oluşmasında da dinin rolü vardır. Din, kadın ve erkeğe verdiği rol ve statü sebebiyle, toplumda toplumsal cinsiyetin belirlenmesine ve toplumun bu değer ve yargıları kabul etmesine neden olmaktadır (Gürhan, 2010). Dindarlık ve dini mezheplerin ataerkil normların hakim olmasına ve bu yerlerde kadınların birincil rolünün çocuklara bakmak ve ücretsiz ev kadını olarak hizmet etmek olduğu gözlenmektedir. Yapılan çalışmalar sonucunda ataerkil hakimiyetin olduğu yerlerde ekonomik düzeyin düşük ve dindarlık düzeylerinin yüksek olduğunu göstermiştir. Ayrıca yüksek düzeyde dindarlık sergileyenlerin, cinsiyet eşitliğine daha az inandıkları gözlenmiştir (Seguino ve Lovinsky, 2009). Büyük dinlerin çoğu kürtaj ve boşanmayı reddetmekte ve geleneksel cinsiyet rollerini desteklemektedir. Neredeyse bütün dinler kadınlara bir kutsiyet atfetmektedir. Dini davranışların, cinsel ahlak ve cinsiyet eşitliği ile ilgili tutumları güçlü bir şekilde etkilediği görülmektedir. Sonuç olarak, dini kişisel olarak önemli bulan insanların dini görüşlerinin bir sonucu olarak boşanma, kürtaj ve cinsiyet eşitliğini reddetmeleri daha olasıdır (Adamczyk, 2013).

Türkiye'de toplum cinsiyet eşitsizliğini ampirik çalışmalardan hareketle değerlendiren ve cinsiyet eşitsizliğinin çeşitli makro ekonomik göstergelerle ilişkisini ele alan çalışmaların bir kısmı şu şekilde sıralanabilir:

Savaş (2018), toplumsal cinsiyet eşitsizliğinin ölçmek için bir endeks geliştirmiş ve analiz sonucunda bireylerin cinsiyet eşitsizliğine bakış açılarının temel belirleyicileri arasında cinsiyetin, yaşanılan bölgenin, eğitim düzeyinin ve çalışma durumunun olduğunu belirtmiştir.

Sart ve Dalyancı (2018), Dünya Ekonomik Forumu Küresel Cinsiyet Açığı Endeksi verilerinden hareketle Türkiye'deki cinsiyet eşitsizliğini, eğitim, ekonomi, siyaset ve sağlık boyutları ile birlikte 
incelenmiş ve Türkiye'nin özellikle ekonomi boyutunda küresel endeksin altında olduğu fakat sağlık ve eğitim açısından küresel ortalamaya yakın olduğu sonucuna ulaşmıştır.

Tunç (2018), cinsiyet eşitsizliğinin insani gelişmişlik düzeyi üzerindeki etkisini ülkelerarasında farklı gelir grupları için araştırmıştır, elde ettiği bulgular daha düşük gelir ve insani kalkınma düzeyine sahip ülkelerin gelir düzeyi yüksek ülkelere göre toplumsal cinsiyet eşitsizliğindeki artışın insani kalkınma düzeyini daha fazla oranda düşürdüğünü göstermiştir.

İnce Yenilmez (2019) çalışmasında kadın işsizliği ile ekonomik eşitsizlik arasındaki içsel ilişkiyi değerlendirmiş ve kayıt dışı istihdamı azaltmanın, yüksek kaliteli ve üretken işleri teşvik etmenin, kadın işsizliğinden kaynaklanan sorunlarına karşı çözüm üretmek için önemli olduğunu vurgulamıştır.

Özdemir Akgül (2020) çalışmasında toplumsal cinsiyet eşitsizliği ile kadınların güçlendirilmesini etkileyen faktörlerin ve mutluluk endeksi sıralaması ile cinsiyet eşitliği arasındaki ilişkiyi değerlendirmiş ve turizmde kadın istihdamının, cinsiyet eşitsizliğinin azaltılmasının ve toplumun mutluluk düzeyinin birbiriyle ilişkili olduğu sonucuna ulaşmıştır.

Demir (2021), işgücü piyasası temel göstergelerini cinsiyeti dikkate alarak OECD ülkeleri ve Türkiye için değerlendirmiş, işgücü piyasasında cinsiyet eşitsizliği açısından Türkiye'nin konumunu çok boyutlu ölçekleme tekniği ile belirlemiştir. Çalışmada kadınların işgücüne katılım oranları, yönetici olarak çalışan kadınların oranı ve işsizlik oranları dikkate alınmıştır, buna göre kadın işgücü açısından Türkiye'nin diğer OECD ülkelerinden farklı bir yerde olduğu fakat erkek işgücü açısından Türkiye'nin İspanya ve İtalya ile benzerlik gösterdiği sonucuna ulaşılmıştır.

Çolak (2021), Türkiye için toplumsal cinsiyet eşitsizliğinin ve ekonomik büyüme arasındaki ilişkiyi incelemiştir, elde edilen bulgulara göre büyüme, hem ücretli hem de lise ve dengi okul mezunu çalışanlardaki cinsiyetler arası gelir eşitsizliği oranını kadınların lehine olacak şekilde azaltan bir faktördür.

Çelik (2021), Türkiye' de bölgesel kamu yatırımlarının kadın ve erkek istihdamı üzerindeki etkisini 2004-2018 dönemi boyunca 26 bölgeden hareketle incelemiştir. Buna göre, erkek istihdamındaki bölgeler arasında aynı yönlü bir mekânsal etkileşim varken, kadın istihdamında istatistiksel olarak anlamlı bir mekânsal etkileşim bulunmamaktadır. Bölgesel emek verimliliğindeki bir artış, kadın istihdamının daha fazla azalmasına yol açmaktadır.

\section{Metodoloji}

Sosyal bilimlere konu olan çalışmalarda doğrudan ölçülemeyen gizli (latent) değişkenler araştırmacıların karşısına sıklıkla çıkmaktadır. Bu değişkenlere ilişkin çıkarsamalar gözlemlenebilen ve/veya ölçülebilen değişkenlere dayalı modellerle mümkündür. Gizli Sınıf Analizi de gözlemlenebilen ve/veya ölçülebilen değişkenleri kullanarak bir kitledeki gizli alt grupları tanımlama için kullanılan bir istatistiksel analizdir. Türkiye' de cinsiyet eşitsizliğine bakış açısı gizli değişken olarak, anketteki sorular ise gözlenen değişkenler olarak kabul edilmiştir.

Bu çalışmada Gizli Sınıf Analizi kullanılmıştır. Sosyal ve davranış bilimlerinde zeka, yaşam kalitesi gibi kuramsal değişkenleri sayısal olarak ortaya koyması Gizli Sınıf Analizinin temel mantığıdır. Gizli Sınıf Analizi bazı kategorik gözlenen değişkenler ile kategorik gizli değişkenlerin bulunduğu durumlarda bahsedilen değişkenler arasındaki ilişkinin ortaya çıkartılmasını hedeflemektedir. Gizli Sınıf Analizi ,'Faktör Analizi'nin kategorik değişkenler için alternatifi"'olarak tanımlanır (Çilan, 2015). Gizli Sınıf Analizinde, C değişkeninin kategorileri için $A$ ve $B$ değişkenlerinin birbirinden bağımsız olduğu bilinsin ve bu ilişki her bir i, j, k kombinasyonunun oranı için A değişkeninin koşullu olasılığı $\left(P_{i k}^{\bar{A} C}\right)$, B değişkeninin koşullu olasılığı $\left(P_{i k}^{\bar{B} C}\right)$ ve $C$ değişkeninin belirli bir kategorisine düşme olasılığı $\left(P_{k}^{C}\right)$ ile çarpımları bize bu bağımsızlığı gösterir (Özkan, 2015): 


$$
\hat{P}_{i j k}=\hat{P}_{i k}^{\bar{A} C} \times \hat{P}_{j k}^{\bar{B} C} \times \hat{P}_{k}^{C}
$$

C değişkeni gözlenemeyen olduğu zaman, değişkenin açıklayıcı kategorileri ölçülemediği durumlarda olasılıklar $\pi$ olarak gösterilir. X gizli değişkeni gizli sınıfları t sınıfa sahip bir değişken olarak düşünülürse, $\pi$ Eşitlik (2)' deki gibidir (Goodman, 1974):

$$
\pi_{i j t}^{A B X}=\pi_{i t}^{\bar{A} X} \times \pi_{j t}^{\bar{B} X} \times \pi_{t}^{X}
$$

Burada $\pi_{i j t}^{A B X}$, rastgele seçilen bir gözlenen değerin $\mathrm{i}, \mathrm{j}, \mathrm{t}$ hücresinde bulunması başka bir değişle $\mathrm{X}$ gözlenemeyen değişkenin t. sınıfında, A değişkenin i. sınıfında bulunurken aynı anda $B$ değişkeninin j. sınıfında yer alması olasılığıdır. $\pi_{i t}^{\bar{A} X}, \mathrm{X}$ gözlenemeyen değişkenin t. sınıfında bulunan bir gözlemin $\mathrm{A}$ değişkenin i. kategorisinde olması olasılığını gösterirken aynı şekilde $X$ gözlenemeyen değişkenin $t$. sınıfında bulunan bir gözlemin B'nin j. kategorisinde yer alması $\pi_{j t}^{\bar{B} X}$ olarak gösterilir. $\pi_{t}^{X}$ ise rastgele seçilen bir gözlemin X gözlenemeyen değişkenin t. seviyesinde olması olasılığıdır (Goodman, 1974). Bu olasılıklar koşullu olasılık olarak da bilinirler. Yerel bağımsızlık gizli yapı modellerinin en temel varsayım olup burada gözlenemeyen değişken sabit tutulduğunda gözlenen değişkenlerin birbirlerinden bağımsız olduğu düşünülür.

Koşullu ve gizli sınıf olasılıkları Gizli Sınıf Analizinin iki ana parametresi olup, temel amacı en çok olabilirlik tahminlerini saptamaktır (Goodman, 1974).

Gizli sınıf olasılıkları, gizli değişkenin her bir kategorisinin gerçekleşme olasılığını göstermek üzere birbirinden yerel olarak bağımsız gözlemlenen ölçümlerin de olduğu gözlenemeyen değişkenlerin sınıflarının dağılımını gösterir.

Gizli sınıf olasılıklarını etkileyen dikkat edilmesi gereken iki parametre vardır. Bunlar sırasıyla: Gizli değişkendeki sınıf sayısı (t) ve bu sınıfların göreceli boyutlarıdır(Özkan, 2015). Gizli sınıflar, bir değişken kümesine göre birimleri yapılandıran boyutlardır. Değişkenler arasında sadece rastgele ilişki olması için bütün gizli sınıfların kontrol altına alınması gerekir. Gizli Sınıf Analizi gözlemleri, denekleri, olguları ve bireyleri aralarında koşullu bağımsızlık olan gizli sınıflara ayııır (Çilan, 2015).

Gizli Sınıf Modellerini tahmin ederken çoğunlukla, parametreleri 0-1 arasında olan En Çok Olabilirlik Tahmin Yöntemi (Maximum Likelihood) kullanılmaktadır. En Çok Olabilirlik Yönteminin, Beklentinin Maksimize Edilmesi (EM) ve Newton-Raphson olmak üzere iki tane tekrarlayan/benzer algoritması bulunur (Çilan, 2015).

Tahminleri elde etmek için genel olarak eşitlik (3)'den yararlanılır (Çilan, 2015).

$$
\hat{\pi}_{i j k t}^{A B C X}=\hat{\pi}_{i t}^{\bar{A} X} x \hat{\pi}_{j t}^{\bar{B} X} x \hat{\pi}_{k t}^{\bar{C} X} x \hat{\pi}_{t}^{X}
$$

Ki-Kare $\left(X^{2}\right)$ Uygunluk Testi, Olabilirlik Oran $\left(G^{2}\right)$ Testi ve Standardize artıklar yöntemleriyle modelin uygunluğu araştırılabilir. Oran ve Ki-Kare testlerinde sıfır ve alternatif hipotezler kurulur ve aşağıdaki gibidir:

$\mathrm{H}_{0}=$ Model kullanım için uygundur.

$\mathrm{H}_{1}=$ Model kullanım için uygun değildir .

$\mathrm{H}_{0}$ hipotezinin kabul edilmesi durumunda "model uygun" kabul edilmekte olup reddedildiği takdirde model uygun değildir" ve başka bir model seçilmesi gerekmektedir.

Kontrol değişkenin $\mathrm{k}$. , $\mathrm{X}$ satır değişkeninin i. ve $\mathrm{Y}$ sütun değişkeninin j. sütununda yer alan gözlenen frekans ve beklenen frekans sırasıyla $F_{i j k}$ ve $f_{i j k}$ olmak üzere; Pearson Ki-kare İstatistiği aşağıdaki gibi hesaplanır (Çilan, 2015): 


$$
\chi^{2}=\sum_{i j k} \frac{\left(F_{i j k}-f_{i j k}\right)^{2}}{f_{i j k}}
$$

\section{Veri Kümesi}

Bu çalışmada Türkiye'de yaşayan "Cinsiyet Eşitsizliği" hakkında farklı düşüncelere sahip bireyleri sınıflandırmak, bu konudaki bakış açılarını değerlendirmek ve profillerini belirlemek amacıyla Dünya Değerler Araştırmasına ait 2014 yılı verileri kullanılmıştır. Ankete Türkiye'den 1265 kişi katılmıştır. Dünya Değerler Araştırması 1981 yılından beri periyodik aralıklarla yaklaşık 100 ülkede yaşayan bireylerin değerlerini, inançlarını ve bu değerlerinin zaman içinde nasıl değiştiklerini ayrıca bu değerler üzerindeki sosyal ve politik etkileri inceler. Dünya Değerler Araştırması'nda kişilerin sosyo-demografik bilgilerinin yanı sıra, "Cinsiyet Ayrımcılığı" ile ilgili yaklaşımlarının saptanabileceği sorulara da yer verilmiştir. Bu anketteki, katılımcıların "Cinsiyet Ayrımcılı̆̆ı" hakkındaki düşüncelerinin değerlendirilebileceği 8 soru ile cinsiyet ayrımcılığı hakkındaki düşünceler üzerinde etkili olduğu düşünülen eğitim, yaş, cinsiyet, sosyal statü, medeni hal, dindarlık, çocuk sayısı, ekonomik memnuniyet, politik sınıflandırma ve ülkenizde insan haklarına duyulan saygıya ilişkin sorular dikkate alınmıştır. Bu sorulardan eğitim, yaş, cinsiyet, sosyal statü, medeni hal, dindarlık, çocuk sayısı, ekonomik memnuniyet, politik sınıflandırma ve ülkenizde insan haklarına duyulan saygı üzerine olanlar eş değişken "Cinsiyet Eşitsizliğine Bakış Açısı" gizli değişken olarak tanımlanmıştır. Değişkenler Şekil 1'de yer alan araştırma modeli ile temsili olarak sunulmuştur.

Şekil 1. Araştırma Modeli

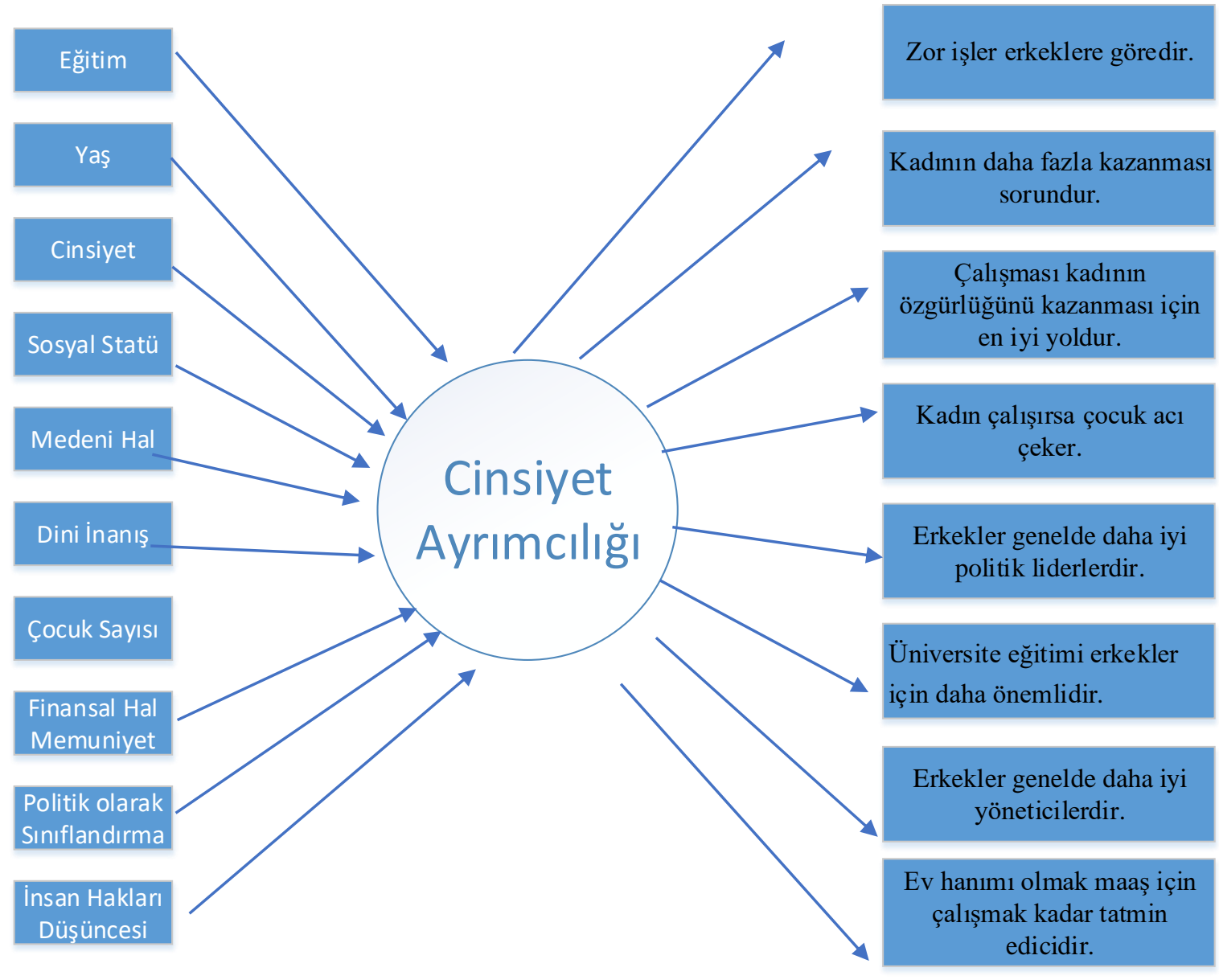




\section{Bulgular}

Modeller arasında seçim yapılırken AIC, BIC ve Maximum Likelihood kriterlerine bakılarak değerlendirme yapılmalıdır. Bu nedenle ilk aşamada modelde yer alan sınıf sayısı belirlemek amacıyla AIC, BIC kriterleri ve serbestlik dereceleri dikkate alınarak olası modeller değerlendirilmiştir.

Anket verilerinin $\mathrm{R}$ programına yüklenmesi sonucunda $\mathrm{R}$ programından elde edilen çıktılara göre denenen 2, 3 ve 4 sınıflı modellere ait değerlendirme kriterleri aşağıdaki kriter tablosunda özetlenmiştir.

Tablo 1. Sınıflandırma Kriter Tablosu

\begin{tabular}{|c|c|c|c|c|}
\hline & Serbestlik Derecesi & AIC & BIC & Max.Likelihood \\
\hline $\mathbf{4}$ sinff & 1148 & 21550 & 22152 & -10664 \\
\hline 3 sinff & 1180 & 21727 & 22164 & -10778 \\
\hline $\mathbf{2}$ sinff & 1212 & 22201 & 22474 & -11047 \\
\hline
\end{tabular}

Yukardaki tabloya göre AIC ve BIC kriterleri 3 sınıflı modelden 4 sınıflı modele geçerken büyük ölçüde azalma göstermemiştir. Ancak Maksimum Likelihood'a göre en küçük değere sahip olan 2 sınıfı modelin seçilmesi gerekmektedir. Bu nedenle sonuçları değerlendirmek için 2 sınıflı model incelenecektir.

2 sınıfı modelde elde edilen gizli sınıf olasılıkları yaklaşık olarak 0.69 ve 0.31 'dir. Aşağıdaki şekilde uzun olan çubuklar daha önce açıklandığı gibi olasılık değerinin 1'e yakın olduğu durumları yani sorulan soruya aşağıdaki şeklin sağ kısmındaki cevaplardan (kesinlikle katılıyorum, katılıyorum, katılmıyorum, kesinlikle katılıyorum) hangisini yoğun olarak tercih ettiğini temsil etmektedir.

Şekil 2. 2 Sınıfıı Modele Ait Koşullu Olasılıklar ve Gizli Sınıf Olasılıklarına Ait Diyagram

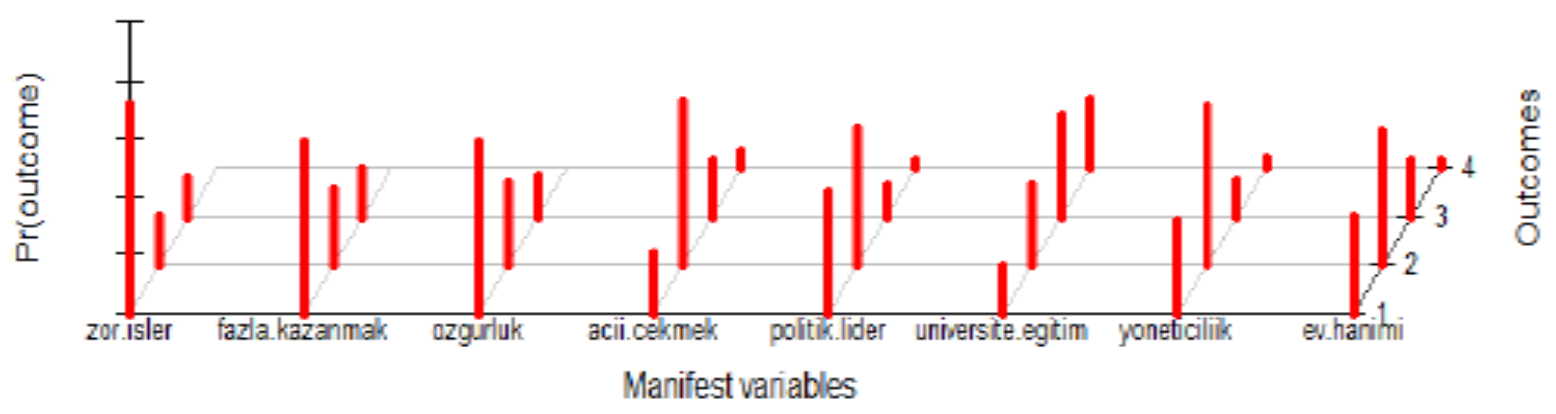

Class 2: population share $=0.306$

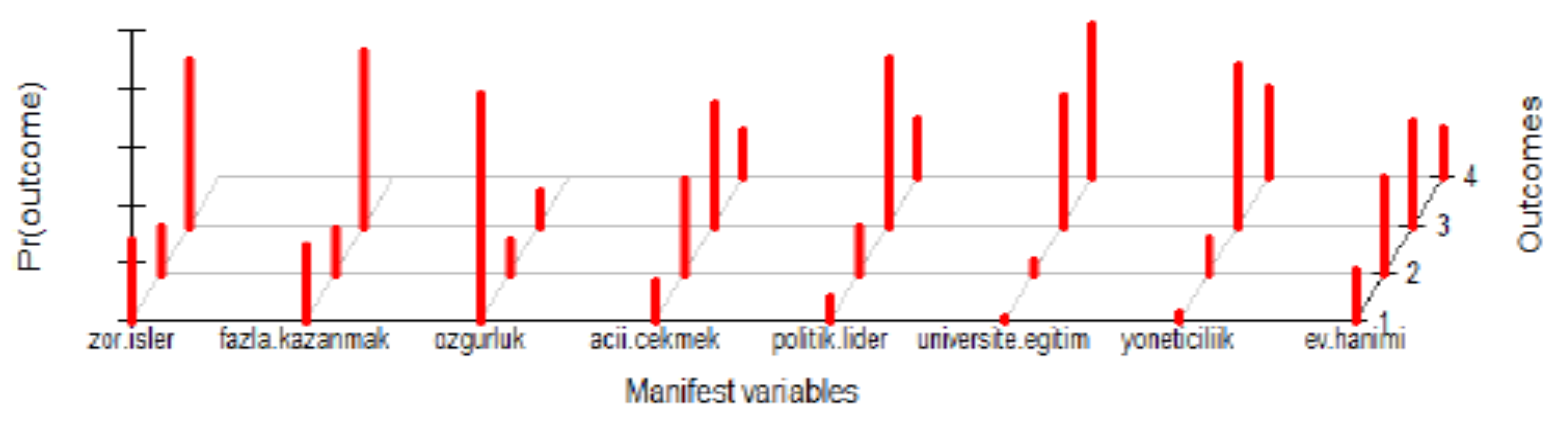


Buna göre, yukarda belirtildiği gibi her 2 sınıf içinde benzer cevapların verildiği sorulardan farklı olarak koşullu olasılıklar göz önünde bulundurularak bir sonraki tablo oluşturulmuş ve sınıflar isimlendirilmiştir.

Tablo 2: 2 Sınıflı Modele Ait Sonuçlara Göre Çıkarım ve İsimlendirme Tablosu

\begin{tabular}{|c|c|}
\hline Sinif & Çıkarım \\
\hline Gelenekselci & $\begin{array}{l}\text { - 1.sınıfta yer alan bireyler, kitlenin yaklaşık \%69'unu oluşturmaktadır ve } \\
\text { bu sınıftaki bireylerin dahil olduğu sınıf "Gelenekselci" olarak } \\
\text { isimlendirilmiştir. } \\
\text { - Bu sınıftaki bireyler, "Zor işler erkeklere göredir", "Kadının fazla } \\
\text { kazanması sorundur", "Kadının çalışması özgürlüğünü kazanması için en } \\
\text { iyi yoldur", "Kadın çalışırsa çocuklar acı çeker", "Erkekler daha iyi politik } \\
\text { liderlerdir", "Erkekler daha iyi yöneticilerdir" ve "Ev hanımı olmak maaş } \\
\text { için çalışmak kadar tatmin edicidir" sorularına katılmaktadır. } \\
\text { - Son olarak Gelenekselci sınıftaki bireyler, "Üniversite eğitimi erkekler için } \\
\text { daha önemlidir" sorusuna katılmamaktadır. }\end{array}$ \\
\hline $\begin{array}{l}\text { Gelenekselci } \\
\text { Olmayan }\end{array}$ & 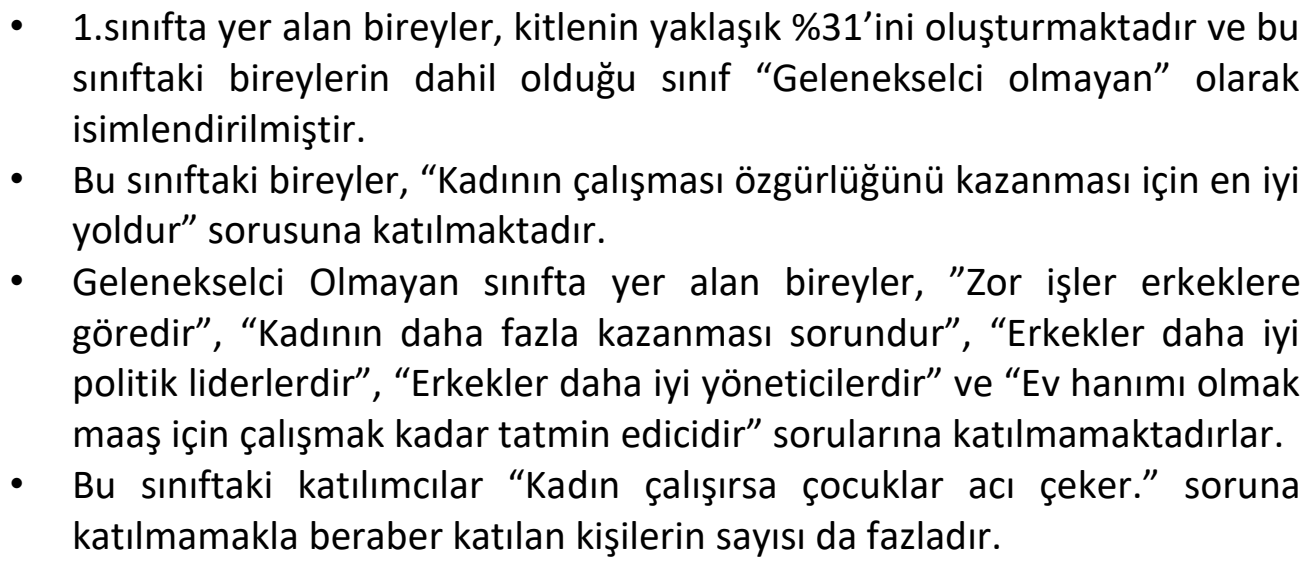 \\
\hline
\end{tabular}

Koşullu olasılık değerleri ise Tablo 3'te yer almaktadır:

Tablo 3. 2 Sınıfı Modele Ait Koşullu Olasılıklar Tablosu

\begin{tabular}{|l|lc|}
\hline & Sınıf 1 & Sınıf 2 \\
\cline { 2 - 2 } & \multirow{2}{*}{ Gelenekselci } & $\begin{array}{c}\text { Gelenekselci } \\
\text { Olmayan }\end{array}$ \\
\hline Zor işler & & 0.2797 \\
\hline Katılıyorum & 0.7106 &
\end{tabular}




\begin{tabular}{|c|c|c|}
\hline $\begin{array}{cc}\mathrm{Ne} & \text { katılıyorum } \\
\text { katılmıyorum } & \end{array}$ & 0.1652 & 0.1601 \\
\hline Katılmıyorum & 0.1242 & 0.5601 \\
\hline Fazla Kazanmak & & \\
\hline Katılıyorum & 0.5816 & 0.2572 \\
\hline \begin{tabular}{|cc}
$\mathrm{Ne}$ & katılıyorum \\
katılmıyorum &
\end{tabular} & 0.2797 & 0.1482 \\
\hline Katılmıyorum & 0.1614 & 0.5946 \\
\hline Özgürlük & & \\
\hline Katılıyorum & 0.5859 & 0.7790 \\
\hline $\begin{array}{ccc}\text { Ne } & \text { katılıyorum } \\
\text { katılmıyorum } & & \text { ne }\end{array}$ & 0.2796 & 0.1075 \\
\hline Katılmıyorum & 0.1345 & 0.1134 \\
\hline \multicolumn{3}{|l|}{ Acı Çekmek } \\
\hline Kesinlikle Katılıyorum & 0.2026 & 0.1296 \\
\hline Katılıyorum & 0.5602 & 0.3133 \\
\hline Katılmıyorum & 0.1866 & 0.4060 \\
\hline Kesinlikle katılmıyorum & 0.0506 & 0.1512 \\
\hline \multicolumn{3}{|l|}{ Politik Lider } \\
\hline Kesinlikle Katılıyorum & 0.4123 & 0.0831 \\
\hline Katılıyorum & 0.4634 & 0.1532 \\
\hline Katılmıyorum & 0.1052 & 0.5721 \\
\hline Kesinlikle katılmıyorum & 0.0191 & 0.1917 \\
\hline \multicolumn{3}{|l|}{ Üniversite Eğitimi } \\
\hline Kesinlikle Katılıyorum & 0.1532 & 0.0144 \\
\hline Katılıyorum & 0.2716 & 0.0325 \\
\hline Katılmıyorum & 0.3378 & 0.4376 \\
\hline Kesinlikle katılmıyorum & 0.2373 & 0.5155 \\
\hline \multicolumn{3}{|l|}{ Yöneticilik } \\
\hline Kesinlikle Katılıyorum & 0.3162 & 0.0297 \\
\hline Katılıyorum & 0.5374 & 0.1224 \\
\hline Katılmıyorum & 0.1198 & 0.5468 \\
\hline Kesinlikle katılmıyorum & 0.0266 & 0.3010 \\
\hline
\end{tabular}




\begin{tabular}{|c|c|c|}
\hline Ev hanımı & & \\
\hline Kesinlikle Katılıyorum & 0.3311 & 0.1688 \\
\hline Katılıyorum & 0.4565 & 0.3211 \\
\hline Katılmıyorum & 0.1920 & 0.3497 \\
\hline Kesinlikle katılmıyorum & 0.0204 & 0.1604 \\
\hline
\end{tabular}

Yukarıda tabloda yer alan koşullu olasılık değerleri aşağıdaki gibi özetlenebilir;

* "Kadın çalışırsa çocuklar acı çeker" sorusuna 2.sınıftaki katılımcıların katılmadığı görülürken katılanların oranı \%43 ile yüksek bir orana sahiptir.

* "Erkekler daha iyi politik liderlerdir" sorusuna 1.sınıftaki katılımcıların yüksek oranda yani \%88 ile katıldığı görülmektedir.

* "Erkekler daha iyi politik liderlerdir" sorusuna 1.sınıftaki katılımcıların yüksek oranda yani \%88 ile katıldığı görülmektedir.

* "Erkekler daha iyi yöneticidir" sorusunda ise "Gelenekselci Olmayan" sınıf \%85 ile katılmıyor iken "Gelenekselci" sınıf \%85 ile katılmaktadır.

Bir sonraki aşamada ise eş değişkenlerin anlamlılığı değerlendirilmiştir.

Tablo 4. 2 Sınıflı Modele Ait Değişkenlerin Anlamlılık Tablosu

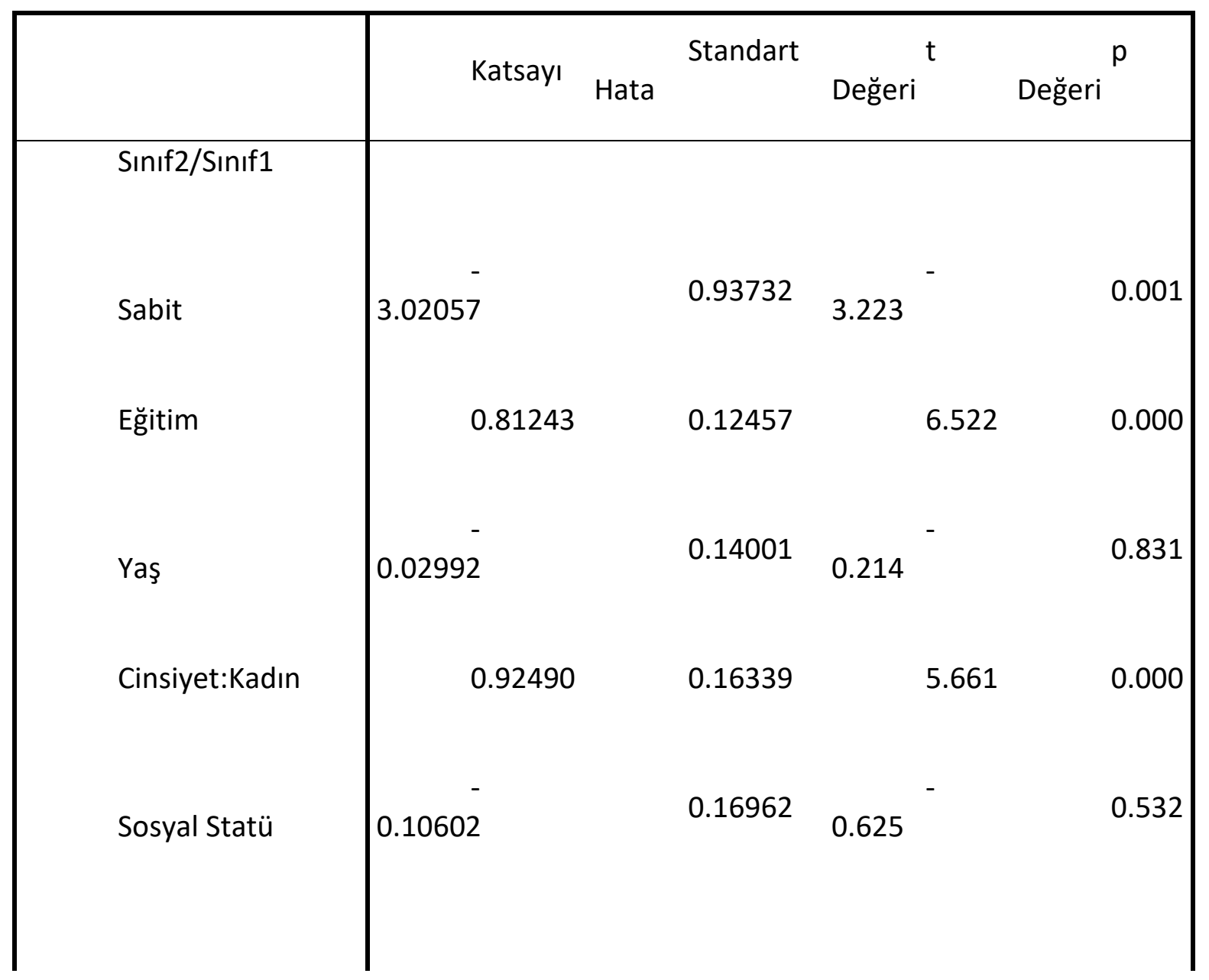




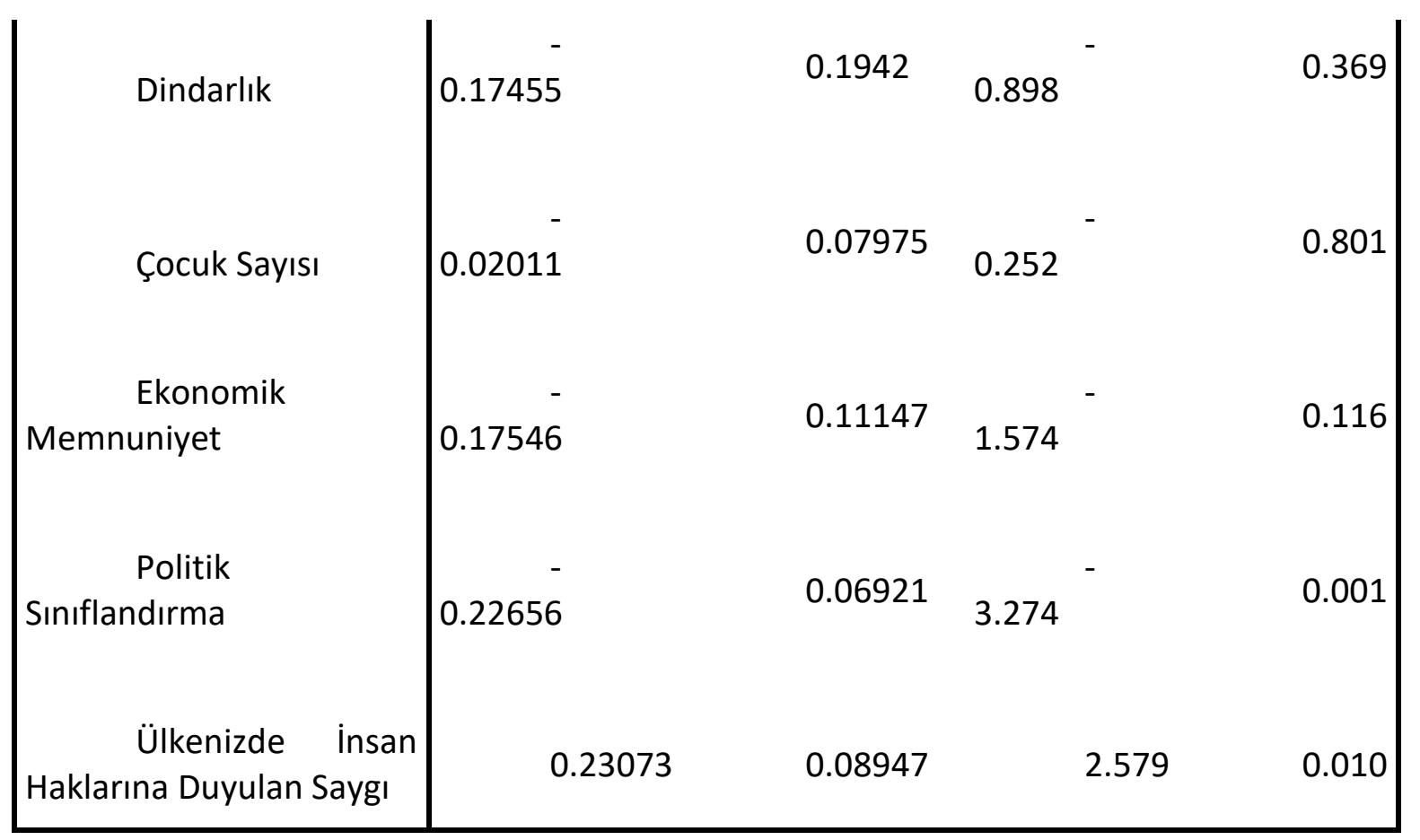

Yukardaki tabloya göre, bir bireyin "Gelenekselci" sınıf yerine "Gelenekselci Olmayan" sınıfına dahil olma olasılığı, eğitim ve insan haklarına duyulan saygı değişkenin kategorilerinin artması halinde artarken, politik olarak sınıflandırma değişkenin kategorisinin azalması ve bireyin kadın olması halinde artar.

Yani bir bireyin politik olarak sola eğilimli olması ve ülkede insan haklarının olmadığını düşünüyorsa, eğitim düzeyi yüksek ve cinsiyeti kadın ise bu bireyin gelenekselci olmayan sınıfta yer alma olasılığı daha yüksektir.

Grupların belirleyiciliği üzerinde literatürde yer verilen çalışmalardan farklı olarak yaş, sosyal statü, ekonomik memnuniyet, dindarlık eş değişkenlerinin istatistiksel olarak anlamlı olmadığı görülmektedir. Başlangıç modelinde medeni hal değişkeninin anlamlı olmadığının görülmesi üzerine, medeni hal değişkeninin kategorilerinin fazla sayıda olan kategorilerinin serbestlik derecesinin düşmesine neden olacağı düşüncesiyle Tablo 4'te yer alan modelde medeni hal değişkenine yer verilmemiştir.

\section{Sonuç}

Bu çalışmada, Türkiye yaşayan bireylerin cinsiyet eşitsizliğine bakış açıları, Dünya Değerler Anketi'nde yer alan sorulardan hareketle, bireylerin demografik ve sosyo-ekonomik özelliklerinin yanı sıra politik görüşleri ve dindarlık düzeyleri dikkate alınarak sınıflandırılmıştır. Söz konusu bakış açısının sınıflandırılması için bir kategorik veri analiz yöntemi olan Gizli Sınıf Analizi kullanılmıştır.

Bireylerin eğitim düzeyi, cinsiyeti, insan haklarına duydukları saygının düzeyi ve politik görüşleri cinsiyet eşitsizliğine bakış açılarını şekillendirmekte öne çıkmaktadır. Elde edilen bulgulara göre, Türkiye'deki bireyler cinsiyet eşitsizliğine bakış açıları açısından iki sınıfa ayrılır. Bu sınıflar "Gelenekselci" ve "Gelenekselci Olmayan" şeklinde isimlendirilmiştir. Bu iki sınıftaki bireylerden "Zor işler erkeklere göredir", "Kadının daha fazla kazanması sorundur", "Erkekler daha iyi politik liderlerdir", "Erkekler daha iyi yöneticilerdir" ve "Ev hanımı olmak maaş için çalışmak kadar tatmin edicidir" yargılarına katılanlar "Gelenekselci" ve bu yargılara katılmayanlar ise "Gelenekselci Olmayanlar" olarak sınıflanmıştır. Bir bireyin "Gelenekselci" sınıf yerine "Gelenekselci Olmayan" sınıfta yer alması olasıllığ, bireyin eğitim düzeyinin yüksek olması, kadın olması, bireyin ülkede insan haklarına yeterli saygı gösterilmediğini düşünen bir birey olması ve politik olarak sola eğilimli olması halinde artar. 
Literatürdeki çalışmalardan farklı olarak bu çalışmada, cinsiyet eşitsizliğine bakış açısını etkileyen faktörler detaylı bir şekilde ele alınmış ve toplumdaki bireyler cinsiyet eşitsizliği kavramına bakış açıları dikkate alınarak sınıflandırılmıştır. Cinsiyet eşitsizliğine bakış açısını şekillendirmekte öne çıkan değişkenlere ait bilgi ile araştırmacı ve politika yapıcılara uygun strateji geliştirmeleri konusunda yardımcı olmak amaçlanmıştır.

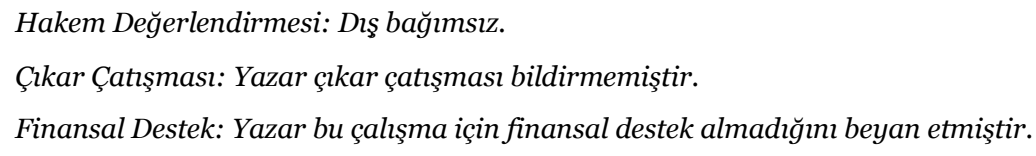

\section{Kaynakça}

Adamczyk,A. (2013). The Effect Of Personal Religiosity On Attitudes Towards Abortion, Divorce And Gender Equality. Does Cultural Context Maka Difference, EURAMERICA, 43 (1), 213-253.

Akkaş, İ. (2019). Toplumsal Cinsiyet Kavramları Çerçevesinde Ortaya Çıkan Toplumsal Cinsiyet Ayrımcılığı. EKEV Akademi Dergisi,23-77, 97-118.

Altuntaş O. ve Altunova H. (2015). Toplumsal Cinsiyet Algısı Ille Sosyo-Ekonomik Değişkenler Arasındaki İlişkinin Belirlenmesi. Turkish Studies, 10(6), 83-100.

Batuhan,Ö. (2015). Kredi Kartı Kullanım Alışkanlıkları Üzerine Gizli Sınıf Analizi (Yüksek Lisans Tezi). Yıldız Üniversitesi Fen Bilimleri Enstitüsü, İstanbul.

Burç, P. (2015). Sosyo-Kültürel Değerler Ve Neoliberalizm Işığında Toplumsal Cinsiyet Eşitliği: Mini Alan Çalışması (İzmir Örneği), Academia. Erişim Adresi: https://www.academia.edu/17167795/

Çelik, O. (2021). Türkiye'de Kamu Yatırımlarının İstihdamdaki Cinsiyet Eşitsizlikleri Üzerine Etkisi: Mekânsal Panel Veri Analizi. Hacettepe Üniversitesi Iktisadi ve Idari Bilimler Fakültesi Dergisi, 39 (2), 191 209. DOI: $10.17065 /$ huniibf.671958

Çiçekli, A. (2019). "Evinin Hanımı Çocuklarının Anası” Olan Kadının Kamusal Alan Mücadelesi. Sosyal Bilimler Araştırma Dergisi, 8 (1), 1-14.

Çilan, Ç. (2015). Uygulamalı Gizli Sınıf Analizi. İstanbul: Çağlayan Kitapevi, İstanbul. Çolak, Z. (2021). Türkiye'de Toplumsal Cinsiyet Eşitsizliği-Ekonomik Büyüme İlişkisi Üzerine Ekonometrik Analiz. MANAS Sosyal Araştırmalar Dergisi, 10 (2), 1094-1105.

Demir, Ö. (2021). Gender Inequality in the Labour Market: Comparison of Turkey and OECD Countries by Multidimensional Scaling Method . Yönetim ve Ekonomi Dergisi, 28 (2), 377-397.

Eastin, J., \& Prakash, A. (2013). Economic Development and Gender Equality: Is There a Gender Kuznets Curve? World Politics, 65(1), 156-186. doi:10.1017/S0043887112000275.

Goodman, L. A. (1974). Exploratory Latent Structure Analysis Using Both Identifiable and Unidentifiable Models. Biometrika, 61(2), 215-231. https://doi.org/10.2307/2334349

Gürhan N. (2010).Toplumsal Cinsiyet Ve Din. E-Şarkiyat Ilmi Araştırmalar Dergisi, 4.

Ince Yenilmez, M. (2019). Gender Inequalıty In Labor Force Partıcıpatıon In Turkey: Closıng The Gender Gap?. Yönetim ve Ekonomi Araştırmaları Dergisi, 17 (3), 40-51.

Kartal, C. (2005). Türkiye'de Kadınların Siyasal Haklarını Kazanmaları ve 1930 Belediye Seçimleri (Yüksek Lisans Tezi). İstanbul Üniversitesi Sosyal Bilimler Enstitüsü, İstanbul. 
Kodan, S. (2013). Üniversite Öğrencilerinin Şiddet Eğilimlerinin Ve Toplumsal Cinsiyet Rollerine iliş̧kin Tutumlarının İncelenmesi. Nesne Psikoloji Dergisi, 1(2),21-43.

Meisenberg G. \&Woodley M. (2015). Studies Gender Differences In Subjective Well-Being And Their Relationships With Gender Equality. Journal Of Happines, 16,1539-1566.

Özdemir Akgül, S. (2020). Turizmde Toplumsal Cinsiyet Eşitliği ve Kadınların Güçlendirilmesi İle Mutluluk Endeksi Arasındaki Illişki The Relatıonshıp Between Gender Equalıty And Women's Empowerment In Tourısm And Happıness Index. Turar Turizm ve Araştırma Dergisi, 9 (2), 160-178.

Poushter J. \& Fetterolf J. (2019). A Changing World: Global Wiews On Diversity, Gender Equality, Family Life And The Importance Of Religion. Pew Research Center, Erişim adresi: https://www.pewresearch.org/global/2019/04/22.

Sart, G. \& Dalyancı, L. (2018). An Analysıs Of Gender Inequalıty With The Dımensıon Of Educatıon, Economy, Polıtıcs And Health In Turkey. Kadın Araştırmaları Dergisi, (16), 96-111.

Savaş, G. (2018). Türkiye’de Yaşayan Bireylerin Toplumsal Cinsiyet Eşit(siz)liği Algısı. Akdeniz Kadın Çalışmaları ve Toplumsal Cinsiyet Dergisi, 1(2), 101-121.

Sayılan F. (2012). Toplumsal Cinsiyet Ve Eğitim. Ankara: Dipnot Yayınları.

Seguino, S., \& Lovinsky, J. (2009). The Impact of Religiosity on Gender Attitudes and Outcomes. Erişim adresi: https://www.semanticscholar.org/paper/The-Impact-of-Religiosity-on-Gender-Attitudesand-Seguino Lovinsky

Tan, M. G. (2018). Türkiye'de Katılımcı Demokrasinin Güçlendirilmesi; Toplumsal Cinsiyet Eşitliğinin İzlenmesi Projesi Raporu. Erişim adresi: https://dspace.ceid.org.tr/xmlui/handle/1/182.

Tunç, M. (2018). Kalkınmada Kadın Ayrımcılığı ve Toplumsal Cinsiyet Eşitsizliğinin Rolü: Ülkelerarası Farklı Gelir Gruplarına Göre Yatay Kesit Analiz. Sosyoekonomi, 26 (38), 221-251. DOI: 10.17233/sosyoekonomi.2018.04.13

Uluocak, Ş.(2014). Toplumsal Cinsiyet Eşitsizliği Ve Kadına Yönelik Şiddet, Edirne: Paradigma Akademi.

Uzgan, Y. S. (2018). Mutlu Toplumun İnşası İçin Toplumsal Cinsiyet Eşitliği. Mor Söyleşiler, İMiR. Erişim adresi: https://www.mmo.org.tr

World Economic Forum (2006). Global Gender Gap Report 2006, Erişim adresi: https://www3.weforum.org/docs/WEF_GenderGap_Report_2006.pdf

World Economic Forum (2020). Global Gender Gap Report 2020, Erişim adresi: http://www3.weforum.org/docs/WEF_GGGR_2020.pdf 